\title{
국내 사회주택 공급현황과 지원정책에 관한 사례연구
}

임병권*

최근 복지수요 증대 및 공공임대주택의 보완수단으로써 사회주택의 중요성은 점차 높 아져가고 있다. 현재 국내의 사회주택은 서울시 등을 중심으로 공급되고 있으며, 지자 체에서 시작된 사회주택 지원정책이 중앙정부 차원으로 확산되는 추세이다. 따라서 본 연구는 서울시의 사회주택 공급현황 및 지원정책에 대해 살펴보았다. 그리고 중앙 정부 차원에서 사회주택 사업자를 지원하기 위한 제도적 장치에 대해 고찰하고 국내 사회주택의 안정적인 정착을 위한 관련 시사점을 모색하였다.

본 연구를 요약하면 다음과 같다. 첫째, 서울시는 사회주택 관련 조례를 제정하여 제도 적 장치를 마련하였고, 토지임대부 방식과 리모델링 방식을 이용하여 사회주택을 공급하 고 있다. 둘째, 서울시는 사회주택 사업자에게 30년 이상의 장기에 걸쳐 저리로 토지를 임대해 주고 있으며, 사회투자기금을 통한 융자, 자체예산을 이용한 보조금지급, 공적보 증을 통한 민간 금융기관 대출과 서울시의 이차보전 등의 제도적 장치를 마련하였다. 셋째, 중앙정부 차원에서 사회주택 융자 상품 및 사회주택 사업자 전용 보증상품이 도 입된 상황이다. 또한, 사회주택 관련 리츠를 통해 사회주택 사업자를 지원 중에 있다. 이상에서 살펴본 바와 같이 국내의 사회주택은 도입 단계에도 불구하고 최근 주택관련 공 적기구를 중심으로 사회주택 활성화를 위한 다양한 지원수단이 도입되고 있다. 따라서 사 회주택 활성화를 위한 보다 다양한 정책적·제도적 지원체계를 구축한다면, 민·관이 상호 협력하는 주거모델인 사회주택의 안정적인 정착에 도움을 줄 수 있을 것으로 사료된다.

핵심어 사회주택, 사회투자기금, 주택금융 공적기금

* 한국주택금융공사 주택금융연구원 연구위원, 경영학박사, bklim@hf.go.kr

※ 본고의 내용은 필자의 개인 의견으로 한국주택금융공사의 공식적인 견해와 다를 수 있습니다. 


\section{I. 서론}

최근 국내시장에서 기존의 임대주택 한계점을 보완 가능한 사회주택(social housing)의 필 요성이 부각되고 있다. 국내의 임대주택시장은 한국토지주택공사(LH)나 지방공사(SH공사 등) 가 공급하는 공공임대주택과 민간의 사업시행자(영리기업 등)가 공급하는 민간임대주택으로 이 원화 되어 있다. 그런데 공공부문은 재정부담 가중과 재원부족에 따른 공급제한 등에 직면해 있 으며, 민간임대주택은 높은 임대료로 인해 임차인의 주거비 부담이 가중되고 있는 실정이다(김 란수, 2015).1) 따라서 민·관 협력 차원의 주거모델인 임대주택(사회주택)의 중요성이 증대되고 있으며, 사회주택의 활성화를 위해 다양한 정책적 지원수단이 도입되고 있다.

전술한 사회주택의 개념은 국가별로 명칭과 정의, 법·제도적 체계, 재원조달 등에서 다양한 차이가 있다. 하지만, 사회주택은 주로 공공·민간·비영리조직이 공급 및 관리하는 공공성이 강 한 주택으로 통용된다(최은영 외, 2016).2) 이와 같은 사회주택은 일정부분 민간자본을 활용하 므로 정부 등 공공부문의 재정지출을 절감하면서 임대주택을 공급할 수 있다. 또한, 사회주택 사업 시행자는 공공으로부터 토지임차, 자금융자, 조세감면 등의 혜택을 통해 사업비 부담을 일 부 줄일 수 있다. 한편, 임차인은 시세보다 저렴한 임대료로 주거 서비스를 제공받을 수 있으며, 민간임대주택에서 발생할 수 있는 빈번한 이주나 임대인과의 갈등 그리고 임대료의 상승으로 인한 주거불안을 상당부분 해소할 수 있는 이점이 있다(심윤수 외, 2016).

사회주택이 활성화된 유럽 국가는 20세기 초에 산업화로 인한 주택부족, 주거환경 악화 및 주거비 상승 등의 문제를 해결할 목적으로 사회주택이 공급되기 시작하였으며, 현재 사회주택 의 비중은 높은 수준을 차지하고 있다(OECD 2016년 통계에 따르면 임대주택 중에서 사회주 택이 차지하는 비중은 네덜란드 $34.1 \%$, 오스트리아 $26.2 \%$, 덴마크 $22.2 \%$ 수준임). 반면, 국내 의 경우에 1970 년대 사회주택을 공급한 사례가 시초이나 활성화 되지는 못하였고, 2010년 이 후에 들어서야 서울시를 중심으로 사회주택 공급이 재개되어 현재 다양한 지원정책을 구비한 상황이다. 하지만 현재까지의 사회주택 공급실적은 기대에 미치지 못하고 있다. 따라서 사회주 택 활성화를 위해서는 추가적인 공적지원 수단을 검토할 필요성이 있는 것으로 사료된다.

1) 공공임대주택은 국고보조금과 주택도시기금의 저리융자를 받고 있으나 지원금액이 건설원가에 크게 미치지 못 하고 있으며, 임대보증금은 임대사업 종료까지 지속적으로 남아있는 비금융부채로 공공임대주택을 공급할수록 부채가 증가하는 구조이다(심윤수 외, 2016).

2) 사회주택은 국제적으로 (1) 주거 빈곤층도 지불할 수 있는 수준의 임대료, (2) 저소득층을 위한 주택을 일정비율 이상 확보하는 정책, (3) 공공정책에 대한 지역 차원에서의 강한 연대, (4) 안정적인 거주, (5) 양질의 주택, (6) 수혜자의 능동적 참여에 의한 서비스 등을 공통적인 특성으로 꼽아볼 수 있다(UNECE, 2015; 이길제, 2016). 
이상과 같은 배경 하에, 본 연구는 서울시의 사회주택 사례를 토대로 국내의 사회주택 공급현 황에 대해 살펴보고자 한다. 또한, 서울시에서 시행중인 사회주택 지원 프로그램을 소개하고, 최근 중앙정부 차원에서 도입한 사회주택 사업자 전용 융자·보증 및 리츠 상품에 대한 사례연 구를 수행하고자 한다.

본 연구의 구성은 다음과 같다. 제2절에서는 국내의 사회주택 공급현황에 대해 서울시를 중 심으로 살펴보고, 제3절에서는 사회주택 활성화를 위한 서울시의 사회주택 지원정책을 공급자 측면과 수요자 측면으로 구분하여 소개한다. 그리고 제4절에서는 중앙정부 차원에서의 사회주 택 지원정책에 대해 주택금융 공적기금을 중심으로 살펴본다. 마지막으로 제5절에서는 본 연구 를 요약하고 시사점을 제시하고자 한다.

\section{II. 국내 사회주택 공급현황}

국내의 사회주택은 민간으로부터 태동되었는데 1970년대 종교관련 비영리 단체들이 주택을 공급한 사례가 시초이다. 이후 2012년부터 협동조합 등 사회적 경제주체와 학계를 중심으로 청년주거문제와 공공임대주택의 한계 등에 대한 본격적인 고민이 시작되었으며, 민간의 자발적 인 활동은 서울시의 공적 지원을 이끌었다(사회주택백서, 2017). 또한 정부에서 2017년 발표 한 주거복지로드맵(2017.11.29.)에서 민·관 협력 거버넌스 구축을 위한 구체적인 정책실현을 위해 사회적 경제주체에 의한 임대주택(사회주택) 공급 활성화 및 사회주택 사업자 지원 강화를 제시하고 있다. 따라서 민간으로부터 시작된 사회주택은 지자체의 참여를 이끌었고, 현재는 중 앙정부 차원에서 새로운 주거모델로써의 사회주택 활성화를 위한 정책적인 지원을 수행하고 있 는 상황이다.

이상과 같은 사회주택은 공급자 유형에 따라 대표적으로 2 가지로 분류 가능하다(사회주택백 서, 2017). 우선 협동조합 공급형의 경우에는 조합의 형태로 주택을 소유 또는 임차함으로써 주거 마련을 위한 개인의 부담을 경감시키고, 더불어 사는 공동체 주거 생활 방식을 추구한다. 사회적기업 공급형의 경우에는 사회적기업 또는 비영리 조직이 주택을 건설 또는 임차해 공급. 운영함으로써 저렴하고 안정적인 주택을 공급하는 유형이다. 현재 국내의 경우 비영리 조직인 사회적기업 등을 중심으로 한 사회주택 공급모델이 주를 이루고 있으며, 사회주택 공급확대를 위해 사회적기업을 지원하는 방향으로의 정책이 진행되고 있다. 
현재 국내의 사회주택은 서울시에서 시작하여 지자체(수원, 시흥, 전주 등)로 확산되었고, 민 -관 협력체계를 구축하여 공급하고 있는 상황이다. 대표적으로 서울시는 청년층과 서민의 주거 문제에 대응하기 위해 공공과 민간이 상호 협력하는 사회주택을 공급하고 있다. 서울시의 사회 주택은 공적지원 하에 사회적경제주체(사회적기업)가 공급하는 구조이며, 시세 80\% 수준 임대 료와 최장 10 년 동안의 거주기간을 보장한다.

〈표 1〉은 서울시의 사회주택정책 변천사이다. 서울시는 2012년 지역사회문제 개선, 일자리 창출 등의 사회적 가치를 실현하고자 사회투자기금을 설치하였고, 해당 기금 중 일부재원을 활 용하여 사회주택과 관련된 사회적 기업을 지원할 수 있는 방안을 마련하였다.3) 이후 2015년 1 월에「사회주택 활성화 지원 등에 관한 조례」를 제정하여 사회주택을 위한 제도적 지원 장치를 마련하였으며, 리모델링 유형인 빈집살리기 사업과 신축 유형인 토지임대부 사업을 도입하였 다. 그리고 2016년에는 해당 조례에 의거하여 사회주택의 체계적인 관리를 위해 중간지원조직 형태인 '서울특별시 사회주택종합지원센터'를 설립함으로써 사회주택의 활성화를 위해 노력하 고 있다.

\section{<표 1> 서울시 사회주택정책 변천과정}

\begin{tabular}{c|l}
\hline 기 간 & \multicolumn{1}{c}{ 내 용 } \\
\hline 2012.07 & ・ 서울시 사회투자기금 설치 \\
\hline 2015.01 & ・ 서울특별시 사회주택 활성화 지원 등에 관한 조례」 제정 \\
\hline 2015.04 & • 빈집살리기 사업 도입 \\
\hline 2015.06 & ・ 토지임대부 사업 도입 \\
\hline 2015.08 & • 사회주택협회 창립 (30여개 사회 경제조직) \\
\hline 2016.03 & • 리모델링형 사업 도입 \\
\hline 2016.06 & • 사회주택지원센터 설립 \\
\hline 2017 현재 & • 사회주택 지원예산 감소(전년대비 30\% 수준) \\
\hline
\end{tabular}

자료 : 박은철 외(2017)

한편, 서울시의 「사회주택 활성화 지원 등에 관한 조례」에 의하면 사회주택의 정의나 지원방 안 등이 구체적으로 명시되어 있다. 해당 조례에 사회주택은 “사회경제적 약자를 대상으로 주거 관련 사회적 경제 주체에 의해 공급되는 임대주택 등을 말한다.”라고 정의되어 있다(서울시 사

3) 서울시의 사회적기업에 대한 지원은 후술되는 3장에 상세하게 기술하였다 
회주택 활성화 지원 등에 관한 조례 제2조 제 1 항). 또한, 사회경제적 약자는 「사회적기업 육성 법」, 「장애인 고령자 등 주거약자 지원에 관한 법률」, 「공공주택 특별법」 등 관련 법률에 따른 주거약자·취약계층·무주택자·청년세대 등이 해당되며4), 주거관련 사회적 경제주체는 비영리 법인, 공익법인, 주택협동조합, 사회적기업 및 중소기업 등으로 명시하고 있다.5)

\section{1. 서울시 사회주택 공급구조}

전술한 바와 같이 서울시의 사회주택은 2015년 시행된 서울시 사회주택 조례 이후 해당 사 업이 본격화 되었다. 현재 서울시의 사회주택 공급 사업은 민관협력 방식에 따라 토지임대부, 리모델링형, 빈집살리기의 3가지 유형으로 구분된다. 또한 신축이나 리모델링 여부에 따라 주 로 신규로 사회주택을 건설하여 공급하는 토지임대부와 리모델링 사업인 리모델링형과 빈집살 리기의 3가지 형태로 구분해 볼 수 있다.

우선 토지임대부 방식은 SH공사가 보유한 공공토지나 매입한 민간토지를 사회주택 사업자 에게 30 40년간에 걸쳐 연간 $1 \%$ 의 저리로 토지를 임대하고, 사업자는 사회주택을 건설 후에 임대·운영하는 구조이다. 다음으로 리모델링형은 주로 1 인 가구를 대상으로 한 임대주택으로 사업자는 15 년 이상 경과한 고시원이나 여관 등의 준주택을 매입하거나 임차한 후에 이를 리모 델링하여 사회주택으로 활용하는 방식이다. 마지막으로 빈집살리기는 6개월 이상 빈집으로 방

4) 구체적인 사회경제적 약자의 범위는 다음과 같다.

가. 「사회적기업 육성법」 제 2 조제 2 호 및 같은 법 시행령 제 2 조에 따른 취약계층

나.「장애인·고령자 등 주거약자 지원에 관한 법률」제 2 조제 1 호의 주거약자

다. 「공공주택 특별법」제 2 조제 1 호의 공공주택 중 국가-서울특별시·서울주택도시공사 또는 한국토지주택 공사 가 소유한 임대주택 거주자

라. 무주택 세대구성원으로서 다른 조례 또는 규칙으로 정하는 바에 따라 공공이 소유하는 임대주택에 입주할 자격이 있는 자

마. 안정적인 주거생활을 영위하기 위해서 적절한 지원을 받을 필요가 있다고 인정되어 서울특별시장(이하 "시 장”이라 한다)이 별도로 정하는 기준에 해당하는 청년1인가구 등

바. 그 밖에 시장이 특별히 인정하는 자

5) 구체적인 사회적경제주체는 다음과 같다.

가.「민법」에 따른 비영리법인

나.「공익법인의 설립·운영에 관한 법률」에 따른 공익법인

다. 「협동조합 기본법」에 따른 협동조합, 협동조합연합회, 사회적협동조합, 사회적협동조합연합회

라.「사회적기업 육성법」에 따라 인증된 사회적기업

마.「서울특별시 사회적기업 육성에 관한 조례」에 따른 예비사회적기업

바. 「중소기업기본법」에 따른 중소기업 중 건설업, 부동산업 및 임대업, 전문, 과학 및 기술 서비스업(건축설 계 및 관련 서비스업에 한함)에 해당하는 기업 
치된 방 3개 이상의 주택을 대상으로 사업자가 리모델링하여 사회주택으로 활용하는 방식이다.

〈표 2〉는 서울시의 사회주택 공급유형별로 대상물건, 임대조건, 입주조건, 거주방식을 비교 한 내용이다. 3 가지 공급유형 모두 공통적으로 시세 $80 \%$ 이하로 운영되며, 입주조건은 주로 도 시근로자 월평균 소득 70\% 이하(주로 소득 5 6분위 이하 대상)로 제한된다.6) 한편, 사회주택 공급유형과 무관하게 거주방식은 공동주택으로 운영되나, 대상물건에서 신축/리모델링에 따라 일부 차이가 있다.

<표 2> 서울시 사회주택 공급유형

\begin{tabular}{|c|c|c|c|}
\hline 구분 & 토지임대부 & 리모델링형 & 빈집살리기 \\
\hline $\begin{array}{l}\text { 대상 } \\
\text { 물건 }\end{array}$ & $\begin{array}{l}\text { - 서울시내 } 100 \text { 평 기준 } \\
\text { • 감정평가액 } 18 \text { 억원 이하 토지 }\end{array}$ & $\begin{array}{l}\text { - } 100 \text { 평 이상 고시원, 숙박시설, } \\
\text { 업무시설 등 비주거용 건축물 }\end{array}$ & $\begin{array}{l}\text { - 다세대, 다가구주택, } \\
\text { 단독주택 (방 3개 이상) }\end{array}$ \\
\hline $\begin{array}{l}\text { 임대 } \\
\text { 조건 }\end{array}$ & $\begin{array}{l}\text { - 시세 } 80 \% \text { 이하 } \\
\text { - 거주기간 보장(10년) } \\
\text { • 임대료인상률 연간 } 5 \% \text { 이내 }\end{array}$ & $\begin{array}{l}\text { - 시세 } 80 \% \text { 이하 } \\
\text { - 거주기간 보장(6-10년) } \\
\text { • 임대료인상률 연간 } 5 \% \text { 이내 }\end{array}$ & $\begin{array}{l}\text { - 시세 } 80 \% \text { 이하 } \\
\text { - 거주기간 보장 (6-8년) } \\
\text { - 임대료인상률 연간 5\%이내 }\end{array}$ \\
\hline $\begin{array}{l}\text { 입주 } \\
\text { 조건 }\end{array}$ & $\begin{array}{l}\text { - 무주택자 } \\
\text { - 도시근로자 월평균 소득 } \\
\text { 70-100\%이하 }\end{array}$ & \multicolumn{2}{|c|}{$\begin{array}{l}\text { - 무주택 1인가구 } \\
\text { - 도시근로자 월평균 소득 70-120\%이하 }\end{array}$} \\
\hline $\begin{array}{l}\text { 거주 } \\
\text { 방식 }\end{array}$ & $\begin{array}{l}\text { - 공동주택으로 운영 } \\
\text { (커뮤니티 공간 셰어) }\end{array}$ & $\begin{array}{l}\text { • 공동주택으로 운영 } \\
\text { (커뮤니티 공간 셰어) }\end{array}$ & - 공동주택으로 운영 \\
\hline
\end{tabular}

자료 : 서울시 사회주택종합지원센터, 진남영(2018)

\section{2. 서울시 사회주택 공급현황}

서울시의 사회주택 공급은 2015년 5월 창립된 사회주택협회 회원사를 중심으로 수행중이며, 사회주택 사업시행·설계·시공·관리 등에 있어 협회 회원사에 속한 다양한 사회적 경제주체가 참여중이다. 사회주택협회는 사회주택의 보급 및 활성화를 위해 구성된 비영리 단체로 2017년 9월 기준으로 나눔하우징, 녹색친구들, 도시마을건축사무소, 두꺼비하우징, 민달팽이 조합 등 49개 회원사가 소속되어 있다.

6) 실제 입주자격은 소득 중심으로 설정되는데, 사회주택에 입주하기 위해서는 공통적으로 무주택세대 구성원이어 야 한다. 그리고 1 인 가구를 대상으로 설계된 경우에는 3 인 가구 도시근로자 소득 기준의 $70 \%$ 이하를 적용하며, 2 인 이상 가구에 대해서는 $100 \%$ 이하, 맞벌이 신혼부부의 경우 $120 \%$ 이하를 적용한다. 한편, 소득금액은 2015 년 기준 각각 월 350만원(70\%), 월 500만원(100\%), 월 600만원(120\%)이다(진남영, 2018). 
〈표 3〉과 같이 서울시의 사회주택 공급은 2015년 사회주택 관련 조례제정 이후 ' 17 년 말까 지 총 663호(3년 누적기준)가 공급된 상황이다. 유형별로 보면 빈집살리기 형태의 사회주택 공 급실적이 246호로 가장 많으며, 토지임대부 사회주택은 198 호로 가장 적게 공급되었다.

<표 3> 서울시 사회주택 공급현황

\begin{tabular}{c|c|c|c|c}
\hline 연도 & 토지임대부 & 리모델링 & 빈집살리기 & 합계 \\
\hline 2015 & 22호 & - & 80 호 & 102호 \\
\hline 2016 & 96 호 & 41 호 & 152호 & 289호 \\
\hline 2017 & 80 호 & 178 호 & 14 호 & 272호 \\
\hline 합계 & 198 호 & 219호 & 246호 & 663호 \\
\hline
\end{tabular}

자료 : 서울시 정보공개자료, 사회주택공급(2018)

사회주택 관련 조례제정 이후 2016년의 사회주택의 공급은 2배 이상 증가하였으나, 2017년 의 경우 소폭 감소한 상황이다. 이는 사회주택 공급에 대한 서울시의 공적 지원책 마련에도 불 구하고, 2017년 지원예산 감소 등에 기인하였기 때문이다(박은철, 2017). 한편, 서울시는 2018년 총 370호의 사회주택 공급 계획을 수립하였으며, 공급 유형별로 각각 토지임대부 총 150호, 리모델링형(리모델링, 빈집살리기) 총 220호를 공급할 예정에 있다.

\section{III. 서울시의 사회주택 지원정책}

현재 서울시는 사업자(사회주택 공급자)와 임차인(수요자)을 대상으로 사회주택 지원 정책을 추진 중에 있다. 사회주택 공급을 활성화하기 위해 사회적경제주체를 대상으로 장기·저리 토지 임대, 기금융자, 보조금지급, 공적보증을 통한 민간대출과 서울시의 이자보전 등으로 지원하고 있다. 또한 사회주택 임차인을 지원하기 위해 융자지원 사업을 수행하고 있다.

\section{1. 사회주택 공급자 지원}

서울시는 토지매입이나 예산보조(보조금지원) 뿐만 아니라 기금융자나 이차보전 등을 통한 간접적인 방법을 활용하여 사회주택 공급자(사회적기업 등)를 지원하고 있다.7)〈표 4〉는 서울 시에서 공급하는 사회주택 유형별로 구분한 재정지원 현황이다. 
우선 서울시에서 직접적으로 사회주택 사업자를 지원하는 방식은 크게 토지매입비 부담이나 보조금지원이 대표적이다. 토지임대부 사업의 경우 〈그림 1)에서와 같이 사회주택 사업자가 희 망하는 토지를 발굴하여 신청하면 서울시(SH공사)는 해당 토지를 매입한다. 이후 사회주택 사 업자는 해당 토지를 연 1\%수준의 임대료로 30년 이상 임차하여 사회주택을 신축(또는 리모델 링) 및 공급한다. 즉, 서울시는 장기·저리로 토지를 제공함으로써 사회주택 사업자가 안정적인 사업을 영위할 수 있도록 지원한다.

다음으로 서울시 보조금은 리모델링 사업(리모델링형, 빈집살리기)을 대상으로 지원 중에 있 다. 리모델링형 사업의 경우에 임대기간에 따라 차등적으로 사업비를 보조하며(최대 2억원 한 도), 빈집살리기의 경우에는 임대주택 전용면적 크기에 따라 보조금(최대 4천만원 한도)을 순차 적으로 지원하고 있다.

\section{<표 4> 서울시 사회주택 유형별 재정지원 현황}

\begin{tabular}{|c|c|c|c|}
\hline 구분 & 토지임대부 & 리모델링형 & 빈집살리기 \\
\hline $\begin{array}{l}\text { 지원 } \\
\text { 방식 }\end{array}$ & • 토지임대 및 융자 등 & - 보조금지원 및 융자 등 & - 보조금지원 및 융자 등 \\
\hline 내용 & $\begin{array}{l}\text { • 토지 저리 융자 } \\
\text { - 총사업비 기금 융자 } \\
\text { - 민간대출 보증 및 서울시 } \\
\text { 이차보전 }(1.5-2 \%)\end{array}$ & $\begin{array}{l}\text { - 사업비 60-80\% 보조 } \\
\text { (최대 2억) } \\
\text { • 기금 융자 } \\
\text { (총 사업비 } 90 \% \text { 이내) }\end{array}$ & $\begin{array}{l}\text { - 사업비의 } 50 \% \text { 보조 } \\
\text { (4천만 원 한도) } \\
\text { • 기금 융자 } \\
\text { (총 사업비 } 90 \% \text { 이내) }\end{array}$ \\
\hline 비고 & $\begin{array}{l}\text { • } 18 \text { 억 한도 토지매입 } \\
\text { • 토지임대료 연 } 1 \% \\
\text { • 30년 이상 장기임대 }\end{array}$ & $\begin{array}{l}\text { - } 6 \text { 년임대 : } 60 \% \text { (1.5억 한도) } \\
\text { - 8년임대 : } 70 \% \text { (1.8억 한도) } \\
\text { - 10년임대 : } 800 \% \text { (2억 한도) }\end{array}$ & $\begin{array}{l}\text { - 전용 } 84 \mathrm{~m}^{2} \text { 이하 : 최대 2천만원 } \\
\text { - 전용 } 165 \mathrm{~m}^{2} \text { 이하 : 최대 3천만원 } \\
\text { - 전용 } 165 \mathrm{~m}^{2} \text { 초과 : 최대 4천만원 }\end{array}$ \\
\hline
\end{tabular}

자료 : 서울시 사회주택종합지원센터, 진남영(2018)

〈그림 1〉은 토지임대부와 리모델링형에 대한 서울시의 사회주택 지원구조를 도식화 한 것 이다. 토지임대부의 경우에 서울시의 토지임대 및 사회주택 사업에 소요되는 사업비(건축비 등)를 사회투자기금을 통해 저리에 융자한다. 또한, 리모델링형의 경우에도 서울시에서 지원 하는 보조금 이외에 사업을 위해 부족한 재원을 사회투자기금 융자상품을 통해 저리에 조달이 가능하다.

7) 민간대출 보증의 경우 주택관련 공적기구(한국주택금융공사, 주택도시보증공사)가 서울시와 업무협약을 맺고 사회주택 사업자를 위한 보증업무를 수행하고 있다. 본 절에서는 서울시에서 직접적으로 수행하고 있는 지원 프로그램을 소개하고, 공적기구의 사회주택 지원현황은 후술되는 4절에서 소개하고자 한다. 


\section{<그림 1> 서울시 사회주택 지원구조}
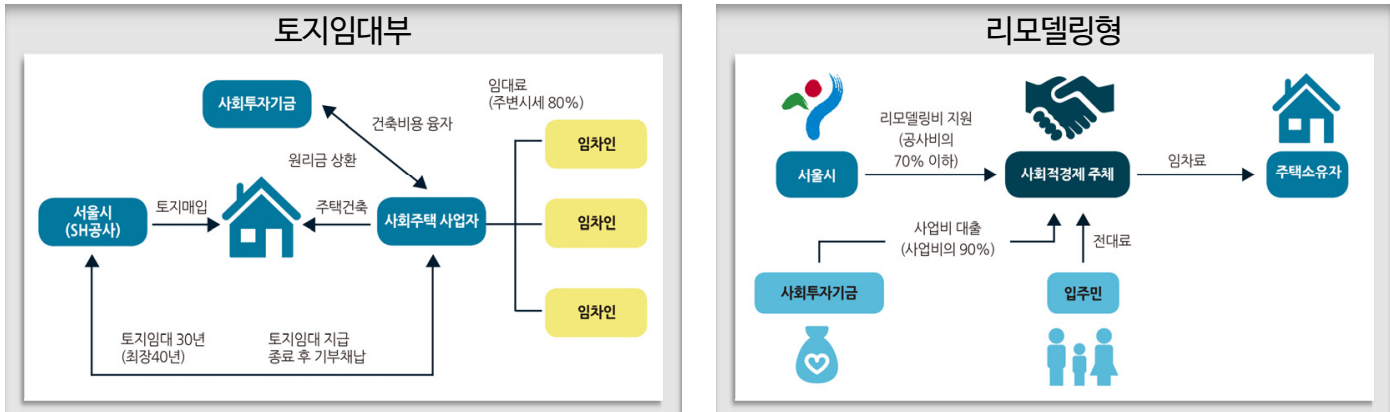

자료 : 최은영 외(2016), 사회주택백서(2017)

사회주택 사업자 간접지원 방식은 전술한 사회주택 사업자 융자지원이나, 민간 금융기관을 통한 사회주택 사업비 융자보증 사업 등이 대표적이다. 우선 사회주택 사업자 융자지원은 2012 년 조성된 서울시 사회투자기금 사업 중에서 “사회투자기금 소셜하우징 융자사업”의 재원을 이 용하여 사회주택 사업자의 재정부담을 완화해 준다. 〈표 5〉와 같이 서울시의 사회투자기금 소 셜하우징 융자사업은 사회주택사업 확대를 위해 조성되었다. 사회투자기금은 사회적경제조직 에게 최장 5 년간에 걸쳐 총 사업비의 $70 \%$ 이내에서 저리로 융자를 제공한다.

\section{<표 5> 사회투자기금 소셜하우징 융자사업}

\begin{tabular}{|c|c|}
\hline 구분 & 내용 \\
\hline 사업목적 & - 다양한 유형의 임대주택 공급 및 사회주택사업 확대 \\
\hline 사업대상 & - 서울 지역에 사회주택을 공급예정인 사회적경제조직 \\
\hline 융자조건 & $\begin{array}{l}\text { - 한도 : 총 사업비의 } 70 \% \text { 이내 } \\
\text { - 기간 및 금리 : } 5 \text { 년, } 2 \% \\
\text { - 상환 : 거치·주택 매각 후 일시상환 }\end{array}$ \\
\hline
\end{tabular}

자료 : 사회주택백서(2017)

한편, 서울시는 한국주택금융공사(HF)나 주택도시보증공사(HUG)와 협약을 맺고 민간 금융 기관 사업비 융자사업을 통해서도 사회주택 사업자를 지원하고 있다. 이는 서울시에서 선정한 사회주택 사업자를 대상으로 공적보증기구를 통해 민간 금융기관에서 융자를 받을 수 있도록 지원하는 상품이다. 사회주택 사업자가 민간 금융기관을 통해 사업비 대출을 받는 경우에 서울 시는 이자에 대한 보전을 지원함으로써(이차보전요율은 $1.5 \sim 2 \% \mathrm{p}$ 사이임) 대출금리에 대한 사 회주택 사업자 부담을 완화하고 있다. 


\section{2. 사회주택 수요자 지원}

서울시의 사회주택 사업자를 대상으로 한 다양한 금융지원 수단과 차별적으로 수요자(입주 자) 측면의 경우에는 '서울시 청년 임차보증금 융자 지원' 사업만 존재하는 상황이다.8)

서울시의 청년 임차보증금 융자지원 사업은 목돈마련이 어려운 취업준비생이나 사회초년생 등의 청년층을 대상으로 임대보증금 대출을 지원하는 사업이다. 모집인원은 연 4,000명이며, 대상주택은 임차보증금이 2천만원 이하이고 월세 70 만원 이하의 보증부 월세 중에서 서울시 관내의 임차전용 면적인 $60 \mathrm{~m}^{2}$ 이하의 주택 및 주거용 오피스텔을 대상으로 한다. 민간 금융기 관은 임차보증금의 $80 \%$ 범위 이내에서 융자를 지원하며, 서울시는 대출금의 연 $2 \%$ 를 이차보전 한다.

전술한 바와 같이 서울시는 사회주택 수요자를 위해 임차보증금 지원상품을 제공하고 있으 나, 대상 물건이 사회주택에 국한되는 것이 아닌 임차주택 전체이며 모집인원이나 융자조건 (융자한도, 대출기간) 등도 제약이 있는 상황이다. 기존 공공임대주택과 사회주택 입주자의 입 주자격이나 소득기준 등은 유사하므로 시세 대비 $80 \%$ 수준의 사회주택 임대료는 입주자가 부 담 가능한 수준을 넘어설 가능성이 있다(최은영 외, 2016). 따라서 사회주택 임차인의 임차보 증금 지원방안 및 임대료(월세) 부담을 경감하기 위해 다각도의 금융지원 방안을 모색할 필요성 이 있다.

<표 6> 서울시 청년 임차보증금 융자 지원사업

\begin{tabular}{|c|c|}
\hline 구분 & 내용 \\
\hline 신청대상자 & $\begin{array}{l}\text { - 만20-39세 이하의 청년 } \\
\text { - 취업준비생 / 사회초년생 (재직기간 5년 이내) } \\
\text { - 신혼부부 (결혼 후 5년 이내) }\end{array}$ \\
\hline 모집인원 & - 연 4,000명 \\
\hline 대상주택 & $\begin{array}{l}\text { - 임차보증금 2천만원 이하 } \\
\text { - 월세 } 70 \text { 만원 이하의 보증부 월세 } \\
\text { - 서울시 관내 주택 및 주거용 오피스텔(전용면적 } 60 \mathrm{~m}^{2} \text { 이하) }\end{array}$ \\
\hline 융자조건 & $\begin{array}{l}\text { - 융자한도 : 임차보증금의 } 80 \% \text { 범위 내 } \\
\text { - 이차보전금리 : 대출금의 연 } 2.0 \% \\
\text { - 대출기간 : } 2 \text { 년 만기 일시상환(2년 단위 3회 연장 가능하며, 최장 8년 이내) }\end{array}$ \\
\hline
\end{tabular}

자료 : 서울시 사회주택종합지원센터 홈페이지

8) 사회초년생이나 청년층을 지원하기 위해 주택도시기금에서는 주거안정월세대출을 저리에 공급하고 있으며(연간 한도 총 960만원, 금리 연 1.5\%), 한국주택금융공사는 월세자금보증 상품(한도 총 864만원)을 제공하고 있다. 본 절에서는 서울시에서 제공하는 수요자(사회주택 입주자) 지원 상품으로만 국한하여 소개하고자 한다. 


\section{$\mathrm{IV}$. 중앙정부 차원의 지원정책 : 주택금융 공적기금 사례 ${ }^{9)}$}

최근 사회주택의 필요성이 증대됨에 따라 중앙정부 차원에서도 사회주택 사업자를 지원하기 위한 제도적 장치를 도입한 상황이다. 이는 대표적으로 사회주택 사업자를 위한 직접적인 융자 나 보증상품 그리고 사회주택리츠로 구분해 볼 수 있다.

\section{1. 사회주택 사업자 융자상품}

사회주택의 공급을 담당하는 사회적경제주체(사회적기업 등)는 재정상태가 열악하며 신용도 가 낮아 자체적으로 사업 재원을 마련하기에 한계가 있다. 따라서 2018년 3월에 주택도시기금 의 재원을 활용한 저리의 융자상품이 신설되었다. 주택도시기금의 저리융자 상품은 사회주택 건설자금 또는 매입자금에 대해 융자를 제공 중이다.

주택도시기금의 융자대상은 관련법령에 따른 사회적경제주체로 한정된다. 그리고 사회주택 매입자금 융자는 8년 이상 임대를 목적으로 시세보다 저렴한 조건으로 민간임대주택을 공급하 는 사업자를 대상으로 한다. 또한, 건설자금 융자의 경우에는 토지를 소유하거나 국가, 지자체, 공공기관 등으로부터 토지를 임대하여 임대주택을 공급하는 자를 대상으로 한다.10) 대상주택 은 가구(세대)당 주거전용면적 $85 \mathrm{~m}^{2}$ 이하인 공동주택 및 단독주택(다가구 포함)이며, 융자금액 은 순담보 가격에 지역별 담보비율(70-80\%)을 적용한 금액을 한도로 한다(수도권 $80 \%$, 광역 시 $75 \%$, 지방 $70 \%$ 로 차등 적용함). 융자기간은 8년 20 년까지로, 1 년 단위로 최대 10 년 추가 연장이 가능하다.

융자조건은 주택유형(공동주택, 단독주택) 및 전용면적별로 차등 적용되며, 해당 조건은 다음 의 〈표 7〉과 같다. 공동주택의 경우에 대출금리는 2.0 2.8\% 수준이며, 대출한도는 최대 1 억원 미만이다. 그리고 단독주택의 대출금리는 $2.0 \%$ 수준이다.

9) 본 장은 한국주택금융공사 주택금융연구원에서 수행한 ‘주택금융 공적기금을 활용한 사회주택 지원방안’ 연구 보고서를 기초로 작성되었다.

10) 사회적경제주체는 「사회적기업 육성법」에 따른 사회적기업, 「협동조합 기본법」에 따른 사회적협동조합 또 는 비영리법인이 해당된다. 
<표 7> 주택유형 및 전용면적별 융자조건

\begin{tabular}{c|c|c|c|c}
\hline \multicolumn{2}{|c}{ 구분 } & $45 \mathrm{~m}^{2}$ 이하 & $45 \mathrm{~m}^{2}$ 초과 $-60 \mathrm{~m}^{2}$ 이하 & $60 \mathrm{~m}^{2}$ 초과- $85 \mathrm{~m}^{2}$ 이하 \\
\hline \multirow{2}{*}{ 공동주택 } & 대출금리 & 연 2.0\%(변동) & 연 2.3\%(변동) & 연 2.8\%(변동) \\
\cline { 1 - 5 } & 대출한도 & 최대 0.5억원 & 최대 0.8억원 & 최대 1억원 \\
\hline \multirow{2}{*}{$\begin{array}{c}\text { 단독주택 } \\
\text { (다가구) }\end{array}$} & 대출금리 & & & 2.0\%(변동) \\
\cline { 2 - 5 } & 둘한도 & & 호당 5억원(가구당 0.6억원) \\
\hline
\end{tabular}

자료 : 주택도시보증공사 홈페이지

\section{2. 사회주택 사업자 보증상품}

최근 주택금융 공적기구인 한국주택금융 공사와 주택도시보증공사는 사회주택 사업자 지원을 위해 사업자보증상품을 도입하였으며, 지자체 및 시중은행 등과 업무협약을 체결하고 사회주택 사업자에 대한 보증업무를 수행 중에 있다. ${ }^{11)}$

우선 한국주택금융공사는 기존에 공급중인 건설자금보증 상품의 요건을 완화한 사회주택 사 업자전용 보증상품을 마련하였는데, 사회적경제주체가 자금을 용이하게 조달할 수 있도록 제한 조건 완화와 더불어 보증한도 확대 등의 지원체계를 도입하였다.12) 특히, 사회적경제주체가 쉽 고 저렴하게 건설자금을 조달할 수 있도록 주택건설실적 및 시공능력 순위 등의 요건을 배제하 였으며, 사회주택의 저렴한 임대료와 낮은 임대료 상승률을 고려하여 대출에 따른 상환조건을 완화하였다(당초 준공 후 매 2 년마다 대출원금의 $5 \%$ 금액을 상환하여야 하나, 자금수입 등을 고려하여 만기 일시상환 허용함).

또한, 건설자금보증에 따른 보증료는 최저수준인 연 $0.1 \%$ 를 적용하며, 보증한도는 총 사업비 의 90\%까지 확대함으로써 사회적경제주체가 임대주택을 공급·운영할 수 있는 주체로 성장할 수 있도록 지원하고 있다. 추가적으로 업무협약을 맺은 시중은행은 10 년 이상 장기대출을 제공 하고, 서울시는 대출금리 부담을 완화하기 위해 최대 $2 \%$ 까지 이자를 보전해 주고 있다. 13$)$

다음으로 주택도시보증공사는 사회주택 사업자 지원을 위해 별도의 보증상품을 출시하였는

11) 한국주택금융공사는 2018년 4월 서울주택도시공사(SH공사), 서울보증보험, $\mathrm{KEB}$ 하나은행과 사회·공동체주택 공급 확대를 위한 업무협약을 체결하였으며, 주택도시보증공사는 2017년 12월 서울시, 우리은행 및 KEB 하나 은행과 사회·공동체주택 금융지원 업무협약을 체결함으로써 사회주택 사업자를 지원하고 있다.

12) 한국주택금융공사 내에 설치된 주택금융신용보증기금에서 주택금융 관련 신용보증업무를 수행중이며, 해당기 금은 주택금융에 대한 신용보증을 통해 주택금융의 장기적·안정적 공급을 촉진하여 국민의 복지증진과 국민경 제 발전을 목표로 한다.

13) 서울보증보험은 임대인의 임대보증금 반환에 대한 보증업무를 수행한다. 
데,14) 사회주택 사업유형에 따라 건설형 사업은 PF(Project Financing)보증을, 그리고 매입형 사업은 매입자금보증 상품을 제공하고 있다. 우선 PF보증은 사회주택 사업자가 건설자금을 저 리에 조달할 수 있도록 금융기관으로부터 받은 건설자금대출의 상환을 보증하는 상품이다. 보 증한도는 총 사업비의 $70 \%$ 이내(지자체 등의 매입확약이 있는 경우 90\%)이고, 보증료는 연 0.220 0.668\% 수준이다(지자체 등의 매입확약 시 연 $0.1 \%$ 적용). 한편, 해당 상품의 이용을 위해서는 공공성, 자기자금 선투입, 시공사요건 등 보증에 따른 필수요건이 존재한다. ${ }^{15)}$

그리고 매입자금보증은 사회주택 매입자금을 저리에 조달할 수 있도록 금융기관으로부터 받 은 매입자금 상환을 보증하는 상품이다. 매입자금보증한도는 지역별·주택유형별로 담보인정비 율을 차등부과하며(50 80\%), 지자체 등의 매입확약이 있는 경우 90\%까지 가능하다. 보증료는 연 $0.278 \%$ 이나 지자체 등의 매입확약 시 연 $0.1 \%$ 를 적용한다.

\section{3. 사회주택리츠 도입}

주택도시기금은 사회주택 사업자에 대한 직접적인 융자 이외에도 사회주택 특화형 리츠(real estate investment trust; REITs)를 설립하거나, 사회주택과 관련된 임대리츠에 출자함으로써 사회주택 사업자를 지원할 수 있는 방안을 도입한 상황이다. 16)

우선 2017년 11월 발표된 정부의 주거복지로드맵(국토교통부, 2017.11)의 구체적인 실천을 위해 2017년 12월 주택도시기금이 총 318억 원을 출자하여 사회주택 허브리츠를 설립하였 다.17) 해당 리츠는 〈그림 2〉와 같이 주택도시기금이 母리츠(허브리츠)에 출자하고 母리츠가 子 리츠(개별리츠)에 출자하는 모자리츠 구조이다. 모리츠에서 출자 받은 개별리츠는 사회주택 건 설 및 매입 사업에 대한 출·융자와 토지임대 등을 수행함으로써 사회주택 사업자를 지원한다.

14) 주택도시보증공사의 경우 사회주택을 사회임대주택으로 명명하나 사회주택과 동일한 의미이다

15) 시세보다 저렴하게 임대주택을 공급하고 일부세대를 주거지원계층에 특별(우선)공급하여야 하며(공공성 요건), 총 사업비의 $5 \%$ 이상 자기자금을 투입하여야 하고(토지임대부사업은 $20 \%$ 이상이나 매입확약이 있는 경우 총사 업비의 $5 \%$, 신용등급 및 과거 건설실적 등 시공사요건을 충족해야 한다(30세대 미만 사업장은 신용등급 C 이상, 시공실적 면제).

16) 부동산투자회사(리츠)는 다수의 투자자로부터 조달된 재원을 이용하여 부동산에 투자, 운용하고 수익을 배분하 는 부동산투자전문 뮤추얼펀드를 의미한다. 한편, 주택도시기금은 1981년 설치된 국민주택기금이 2015년 재 정된 「주택도시기금법」에 근거하여 개편된 기금으로 주택계정과 도시계정으로 구분되어 주거복지 증진과 도 시재생 활성화를 지원한다.

17) 주택도시보증공사 투자 및 출자현황, 2018 공공기관 경영정보공개시스템 


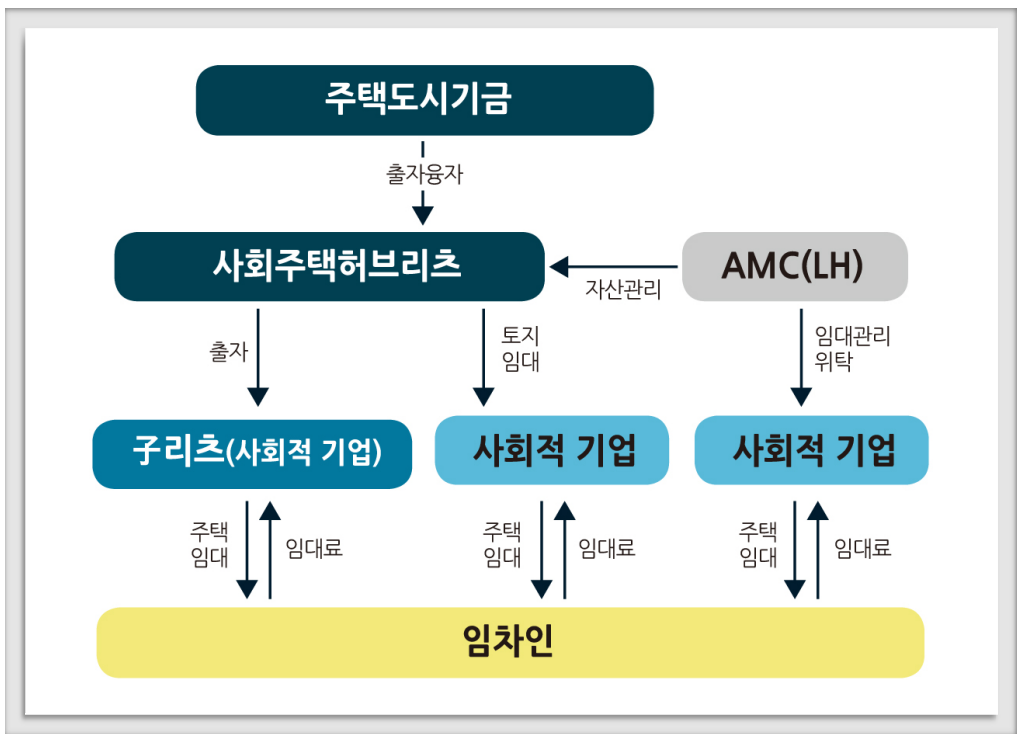

자료 : 주거복지로드맵(2017)

한편, 주택도시기금은 LH공사가 사회주택 허브리츠에 매각한 토지를 사회적 기업에게 10 20년간 임대하도록 하는 토지임대부 시범사업을 추진 중에 있다.18) 사회주택 사업자는 주 택도시기금을 관리하는 주택도시보증공사와 협의하여 사회주택 허브리츠와 토지임대에 대한 계약을 한 후 본격적으로 사업을 추진하는데, 임대기간 종료 후 사회주택 사업자에게 토지매입 권한을 부여하여 사회주택 사업자가 자체적으로 사회주택을 운영할 수 있도록 지원한다.

추가적으로 최근 지자체나 또는 $\mathrm{LH}$ 공사 보유 토지를 임차한 리츠나 지자체 등이 출자한 토 지지원리츠에도 주택도시기금이 출자를 허용하도록 관련 규정을 개정하여 사회주택 사업자를 간접적으로 지원하고 있다. ${ }^{19)}$ 우선 공공에서 운영 중인 임대리츠는 〈표 8〉과 같이 크게 6가지 종류로 구분해 볼 수 있다. 주택도시기금은 6개의 리츠 유형 중에서 사회임대주택 임대리츠 또 는 토지임대부 임대리츠에 출자함으로써 사회주택 사업자를 지원하고 있다. 20)

주택도시기금의 임대리츠 출자요건은 신용등급 $\mathrm{BB}+$, 시공사의 시공능력 평가순위 500 위, 최근 3년간 주택건설 실적 300세대 이상 요건 중 하나 이상만 충족하면 출자가 가능하며(30세

18) 고양삼송(18.03 사업자 선정), 수원조원(18. 06 사업자 선정)에 대해 시범사업이 착수되었는데, 사회적경제주 체는 단독주택 건설 후 저층은 상가로 운영하고 발생 수익으로 임대주택의 임대료를 할인해 주는 형태이다.

19) 기존의 토지임대부는 국가 또는 LH공사가 출자한 리츠에 대해서만 기금출자가 가능한 상황이었다.

20) 임대리츠는 임대사업자가 임대주택을 직접 건설하거나 매입하여 공급하는 것을 목적으로 하는 리츠를 의미한 다(공공지원 민간임대주택 사업추진 안내서, 2018). 
대 미만 건축허가 대상은 신용등급 BB+에서 C 이상으로 추가 완화), 2018년 8월을 기준으로 $\mathrm{SH}$ 공사, 주택도시기금, HUG 보증대출을 각각 $1: 2: 1$ 구조로 자금을 조달하여 토지지원리츠의 설립을 추진 중에 있다.

<표 8> 임대리츠 구분

\begin{tabular}{c|l}
\hline \multicolumn{1}{c|}{ 구분 } & \multicolumn{1}{c}{ 역할 } \\
\hline 사회임대주택 임대리츠 & 사회적경제주체가 공공지원형 장기임대주택을 공급 \\
\hline 토지임대부 임대리츠 & 토지를 임차하여 공공지원형 장기임대주택을 공급 \\
\hline 공공임대리츠 & 공공임대주택을 공급하는 리츠로 주택도시기금과 LH 또는 지방공사가 출자 \\
\hline 공공지원형 민간임대리츠 & 공공지원형 장기임대주택을 공급 \\
\hline 정비사업 임대리츠 & 정비사업의 일반분야분을 매입하여 공공지원형 장기임대주택을 공급 \\
\hline 특화형 임대리츠 & 역세권 등에서 소형평형위주 공공지원형 장기임대주택을 공급 \\
\hline
\end{tabular}

자료 : 공공지원 민간임대주택 사업추진 안내서(2018)

\section{$\mathrm{V}$. 결론 및 시사점}

본 연구에서는 최근 공공임대주택의 보완수단으로써 점차 중요성이 높아져가고 있는 사회주 택에 대해 서울시의 사례를 토대로 공급현황을 살펴보았다. 또한, 서울시에서 시행중인 사회주 택의 지원정책을 살펴보았고, 중앙정부 차원에서의 사회주택 사업자를 지원하기 위한 제도적 장치에 대해 소개하였다. 본 연구의 주요 내용을 요약하면 다음과 같다.

첫째, 서울시는 청년층의 심각한 주거빈곤 문제 및 과도한 주거비 부담 등을 완화하기 위해 사회주택 도입을 모색하였으며, 관련 조례를 제정하여 사회주택 지원을 위한 제도적 장치를 마 련하였다. 특히 사회주택 활성화를 위해 서울시 내에 사회주택종합지원센터를 설립하였으며, 현재 토지임대부 방식과 리모델링 방식을 이용하여 사회주택을 공급하고 있다.

둘째, 사회주택 사업자를 지원하기 위해 서울시는 30년 이상의 장기에 걸쳐 저리로 토지를 임대해 주고 있으며, 사회투자기금을 통한 융자, 서울시 예산을 이용한 보조금지급, 공적보증을 통한 민간 금융기관 대출과 서울시의 이자보전 등의 제도적 장치를 마련하였다. 이를 통해 사회 주택 사업자의 재정 부담을 완화해 주고 있으며, 사회주택 공급 활성화를 도모하고 있다. 또한 사회주택 임차인을 지원하기 위해 청년 임차보증금 융자지원 사업을 수행 중에 있다. 


\section{주백금융영군ㄱ}

셋째, 최근 중앙정부 차원에서 주택금융 공적기금의 사회주택 지원방안이 도입되었다. 우선 주택도시기금을 활용하여 사회주택 사업자에게 직접 융자할 수 있는 상품이 도입되었으며, 사 회적경제주체의 민간 금융시장 접근성을 제고하기 위해 사회주택 사업자 전용 보증상품을 마련 한 상황이다. 또한, 사회주택 특화형 리츠설립 및 임대리츠에 출자함으로써 사회주택 사업자를 지원 중에 있다.

이상에서 살펴본 바와 같이 국내의 사회주택은 도입 단계임에도 불구하고 최근 주택관련 공 적기구를 중심으로 사회주택 활성화를 위한 다양한 정책적 수단이 도입되고 있다. 사회주택을 공급하는 사회적경제주체는 자본력과 신용이 미약하여 재원을 조달하기에 애로가 있으며, 자금 조달비용이 높아 수익성을 보장받기도 어려운 실정이다. 따라서 국내의 안정적인 사회주택 정 책을 위해 사회주택 사업자에 대한 지속적이며 안정적인 지원이 필요한 것으로 사료된다. 또한 사회주택은 공공과 민간이 상호 협력하는 주거모델인 점을 감안할 때, 민간의 참여를 유도하기 위해 사회주택 관련 펀드조성 등을 통한 지원방안을 모색해 볼 수 있을 것으로 판단된다. 한편, 현재 국내의 사회주택은 주로 공급자 위주로 정책적 지원을 수행하고 있다. 따라서 사회주택 입 주자 측면의 정책적·제도적 지원 체계를 구축한다면, 지속적인 수요가 창출 가능하며 안정적인 사회주택 정착에 도움을 줄 수 있을 것으로 판단된다. 결론적으로 공공의 사회적금융 역할 증대 가 필요한 한 시점에서, 사회주택 지원을 통해 주거관련 사회적가치를 창출할 수 있을 것으로 사료된다.

\section{참교문헌}

김란수, 2015, “네덜란드 사회주택의 발전과정과 함의", 협동조합네트워크, 70, 25-56.

박은철, 김수경, 오근상, 2017, “사회주택 활성화 쟁점과 정책과제”, 서울연구원.

심윤수, 김수웅, 이창석, 2016, "토지임대부 사회주택 공급 활성화방안 연구 - 서울시 토지임대부 사회 주택 사업성을 중심으로”, 주택도시연구, 제6권 제2호, 63-77.

주택도시보증공사, 한국토지주택공사, 2018, 공공지원 민간임대주택 사업추진 안내서

진남영, “서울시 사회주택 3개년 정책경과”, 2018서울시 사회주택포럼, 2018.

최은영, 권순형, 진남영, 전진선, 한지은, 2016, “사회주택공급 활성화를 위한 대응방안”, 한국도시연구소. 한국사회주택협회, 2017, 『2017 한국사회주택협회 백서』.

- 논문접수일 : 2018. 11. 2.

- 1차 수정일 : 2018. 11. 20.

- 게재확정일 : 2018. 12. 14. 